\title{
Zeta Potential Change of Neuro-2a Tumor Cells after Exposure to Alumina Nanoparticles
}

\author{
Sergey O. Kazantsev ${ }^{1, \mathrm{a})}$, Alla N. Fomenko ${ }^{1, \mathrm{~b})}$, and Matvey S. Korovin ${ }^{1, \mathrm{c})}$ \\ ${ }^{1}$ Tomsk Polytechnic University, Lenin Avenue 30, Tomsk, 634050 Russia

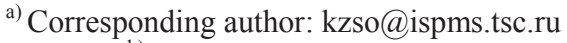 \\ b) alserova@ispms.tsc.ru \\ c) msk@ispms.tsc.ru
}

\begin{abstract}
In recent years, researches have paid much attention to the physical, chemical, biophysical and biochemical properties of a cell surface. It is known that most of the cells' surfaces are charged. This charge depends on the biochemical structure of the cell membranes. Therefore, measurement of a cell surface charge is a significant criterion that gives information about the cell surface. Evaluation of the cells zeta-potential is important to understand the interaction mechanisms of various drugs, antibiotics, as well as the interaction of nanoparticles with the cell surface. In this study, we use the dynamic light scattering method to detect the zeta-potential change of Neuro-2a tumor cells. It has been observed that zeta-potential shifted to negative values after exposure to metal oxide nanoparticles and inducing apoptosis.
\end{abstract}

\section{INTRODUCTION}

The onrush of nanotechnologies offers more and more synthesized nanoparticles and materials based on them. Many concerns arise as regards to their potential toxicity to mammalian and also human cells. The following methods for studying cells characteristics were used: Raman spectroscopy [1], dielectric spectroscopy [2], and NMR spectroscopy techniques [3]. But these methods have a range of disadvantages such as relatively expensive reagents, heating and labour input. In cell biology zeta potential is one of the key physicochemical parameters of nanoparticles exposure on cells (erythrocytes, leukocytes, thrombocytes, etc.) [4], which characterizes the cell surface electrical double-layer potential. The cell-surface zeta-potential depends on the composition of the cytoplasmic membrane and physiological condition of the cells [5]. Previous studies have shown that cancer cells are more electronegative than normal proliferating cells [6].

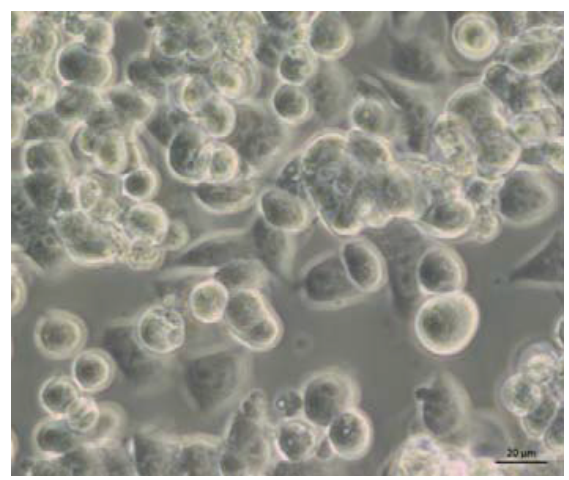

FIGURE 1. Image of Neuro-2a cells 

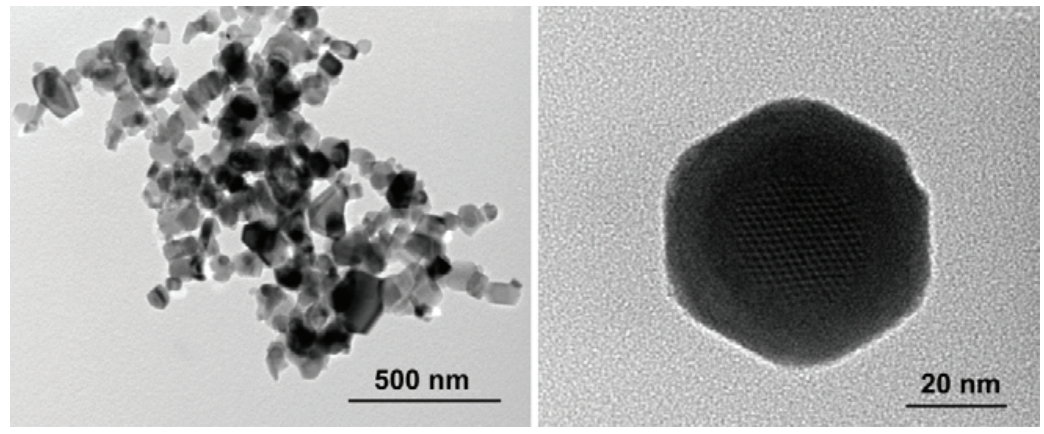

FIGURE 2. TEM image of AlN/Al nanoparticles

Micro-electrophoresis and capillary electrophoresis have been conventionally used for detecting zeta potential of the cells. The electrophoretic light scattering technique based on dynamic light scattering (DLS), in which the frequency shift or phase shift of the laser beam depends on the mobility of particles or cells in an alternating electric field, is a promising alternative to these methods [5].

Alumina is widely used in various medical applications such as regenerative medicine [7,8], cancer treatment [9], drug delivery [10,11] and biosensing methods [12] for its unique physical and chemical properties and low toxicity. Earlier we produced low-dimensional alumina nanostructures by AlN/Al nanoparticles oxidation with water [13-16]. The low-dimensional alumina-based materials have been successfully used as a wound dressing [17]. In vitro studies have shown that low-dimensional alumina structures display different toxic effect on L929 and Neuro2a cell lines. Alumina nanosheets exhibited a more pronounced adverse effect on cells as compared to alumina nanoplates and agglomerates of alumina nanosheets.

In this study, low-dimensional alumina nanostructures were prepared via reaction of the AlN/Al nanopowders with water under different conditions. A Neuro-2A (N2A) mouse neuroblastoma cell line was used to determine the potential toxic effect of the structures. Zeta-potential measurements were used to detect changes in cancer cells (Neuro-2a) surface charge after the exposure to alumina nanoparticles.

\section{MATERIAL AND METHODS}

AlN/Al nanoparticles were produced by the electrical explosion of aluminum wire in a nitrogen atmosphere [1820]. The mass ratio of aluminum and aluminum nitride in the nanopowder was $30: 70 \mathrm{wt} . \%$. There were three methods to obtain low-dimensional alumina nanostructures - the reaction of AlN/Al with water, the hydrothermal synthesis, and the oxidation of AlN/Al in wet air. The reaction of AlN/Al nanopowder with water was carried out according to the method in [13]. For this $1 \mathrm{~g}$ of precursor was added to $100 \mathrm{ml}$ of deionized water. Then, the suspension was incubated on a water bath with stirring at $60^{\circ} \mathrm{C}$ for $1 \mathrm{~h}$. The reaction products were separated by centrifugation, washed several times with deionized water, and finally dried at $120^{\circ} \mathrm{C}$ for $2 \mathrm{~h}$. In the hydrothermal process, $1 \mathrm{~g}$ of AlN/Al nanopowder is treated with $100 \mathrm{ml}$ of deionized water in a stainless steel autoclave with a Teflon insert at room temperature. The hydrothermal treatment was performed at $200^{\circ} \mathrm{C}$ for $6 \mathrm{~h}$. The oxidation of AlN/Al nanopowder in wet air [21] was performed in the climatic chamber TXW-60 at $60^{\circ} \mathrm{C}$ and $80 \%$ relative humidity for $24 \mathrm{~h}$. The reaction products were dried at $100^{\circ} \mathrm{C}$ for $2 \mathrm{~h}$.

The morphology of the low-dimensional alumina structures was examined by scanning electron microscopy (LEO EVO 50, operated at $30 \mathrm{kV}$ ), transmission electron microscopy (JEOL JEM-2100, Japan, operated at $200 \mathrm{kV}$ ), and X-ray diffraction (XRD-6000, Cu- $\mathrm{K}_{\alpha}$ radiation, wavelength $1.54056 \AA$ ). A specific surface area was estimated by nitrogen adsorption on a Sorbtometer M device (Katakon, Russia) and was calculated by the BET method at a relative pressure of $0.05-0.35$.

TABLE 1. Sample characteristics

\begin{tabular}{cccccc}
\hline Sample & Shape & Synthesis method & $\begin{array}{c}\text { Specific surface } \\
\text { area, } \mathbf{~ m}^{\mathbf{2}} \mathbf{g}\end{array}$ & $\begin{array}{c}\text { Zeta potential, } \\
\mathbf{m V}\end{array}$ & $\begin{array}{c}\text { Phase composition } \\
\text { (Fig. 3) }\end{array}$ \\
\hline Sample 1 & Nanopetals & Water oxidation & 280 & 30 & Pseudoboehmite \\
\hline Sample 2 & Nanoplates & Hydrothermal synthesis & 71 & 31 & Boehmite \\
\hline Sample 3 & Wedge-like & Wet air oxidation & 22 & 33 & Bayerit \\
\hline
\end{tabular}




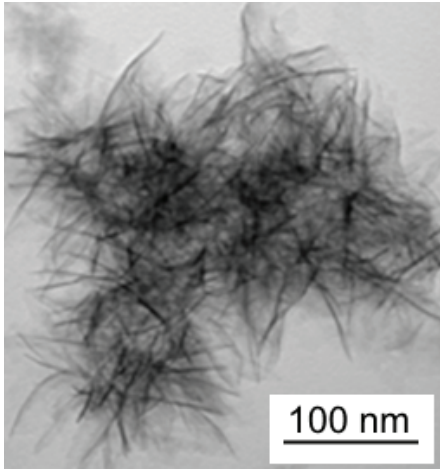

(a)

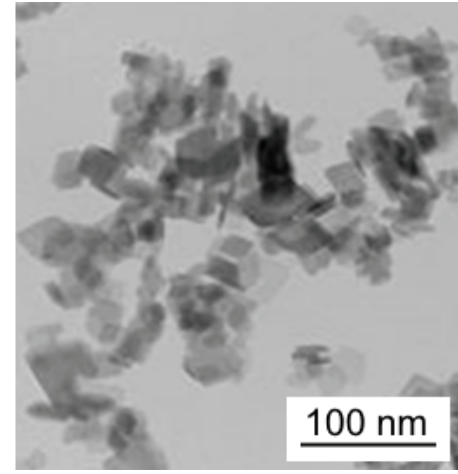

(b)

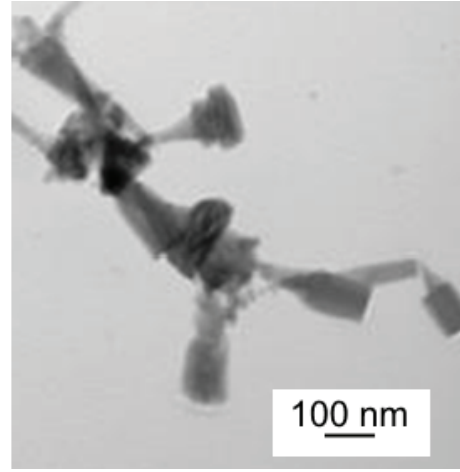

(c)

FIGURE 3. TEM image of alumina nanostructures: (a) alumina nanopetals; (b) alumina nanoplates; (c) wedge-like alumina

The mouse neuroblastoma Neuro-2a cell line (Fig. 1) was purchased from Vector, Koltsovo (Russian Federation). Cells were cultured as monolayer in Eagle's minimum essential medium (MEM) supplemented with $10 \%$ of fetal bovine serum (FBS), $2 \mathrm{mM}$ L-glutamine and $1 \%$ penicillin-streptomycin in $75 \mathrm{~cm}^{2}$ flasks at $37^{\circ} \mathrm{C}$ in a humidified atmosphere containing $5 \% \mathrm{CO}_{2}$. Before treating, samples of alumina nanostructures $(0.08 \mathrm{~g})$ were suspended in $20 \mathrm{ml}$ of culture medium. Cells were seeded on 24-well plates (total volume of $2 \mathrm{ml}$ ) at 160000 cells per well. The suspension of low-dimensional structures $(1 \mathrm{ml})$ was added in each well except for the control one. Cells were incubated for 12,24 , and $48 \mathrm{~h}$.

The number of cells was counted using a hemocytometer with trypan blue staining. The control group was the initial culture with no contact with low-dimensional structures. For statistical data processing, parametric methods with a significance level of $p \leq 0.05$ were used. After incubation, cells were washed three times with Phosphate Buffered Saline (PBS), and then detached using a Trypsin-Versene solution (Invitrogen). After that, cells were centrifuged down and resuspended in PBS ( $\mathrm{pH}$ 7.2) for Zeta-potential measurements. The zeta-potential of the cells was determined using a DLS (dynamic light scattering detector) (Zetasizer Nano ZSP, Malvern Instruments Ltd, $\mathrm{UK}$ ) at $25^{\circ} \mathrm{C}$. Usually, AlN/Al nanoparticles have a faceted form (Fig. 2). According to EDAX-TEM analysis data, aluminum and nitrogen are uniformly distributed throughout all the particles [13]. These particles constitute a composite with a core-shell structure, where the core is the metallic aluminum and the shell is the aluminum nitride.

\section{RESULT AND DISCUSSION}

AlN/Al nanoparticles are chemically active and interact with water at $60^{\circ} \mathrm{C}$. The reaction is exothermic and accompanied by the release of hydrogen and a change in the $\mathrm{pH}$ of the reaction medium. The reaction products have a nanopetal form with the thickness of 5-10 nm and the planar dimension of approximately $150-300 \mathrm{~nm}$ (Fig. 3a). According to the X-ray phase analysis, the main component of these products is a poorly crystallized pseudoboehmite AlOOH (Fig. 4a) [16].

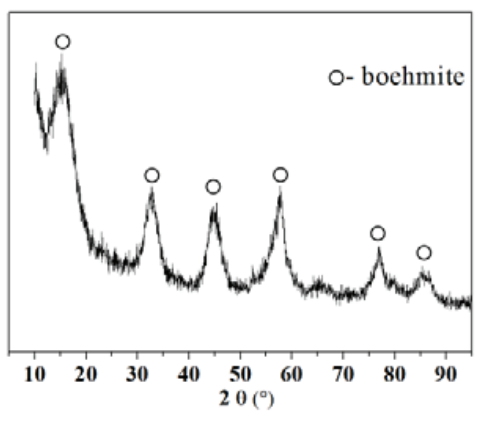

(a)

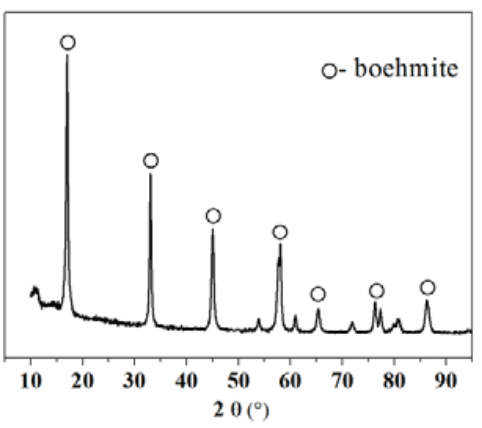

(b)

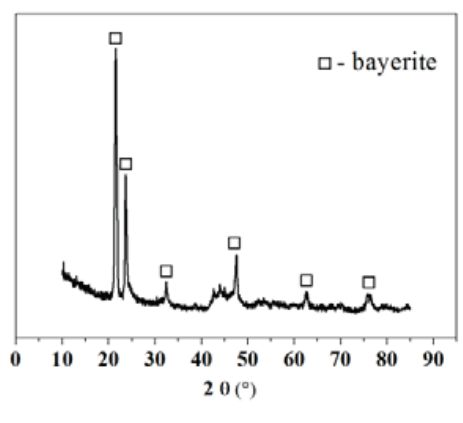

(c)

FIGURE 4. XRD spectra of alumina nanostructures: (a) alumina nanopetals; (b) alumina nanoplates; (c) wedge-like alumina 
TABLE 2. Zeta potential $(\xi)$ and cell viability $(\mathrm{CV})$ of Neuro-2a cells after the exposure to alumina nanostructures

\begin{tabular}{|c|c|c|c|c|c|c|}
\hline \multirow{3}{*}{ Sample } & \multicolumn{6}{|c|}{ Exposure time } \\
\hline & \multicolumn{2}{|c|}{$12 \mathrm{~h}$} & \multicolumn{2}{|c|}{$24 \mathrm{~h}$} & \multicolumn{2}{|c|}{$48 \mathrm{~h}$} \\
\hline & $\xi, \mathrm{mV}$ & $\mathrm{CV}, \%$ & $\xi, \mathrm{mV}$ & $\mathrm{CV}, \%$ & $\xi, \mathrm{mV}$ & $\mathrm{CV}, \%$ \\
\hline Nanopetals & $-25.3 \pm 0.2$ & $100.5 \pm 3.2$ & $-26.3 \pm 0.2$ & $78.4 \pm 2.0$ & $-29.4 \pm 0.3$ & $64.4 \pm 3.3$ \\
\hline Nanoplates & $-22.8 \pm 0.1$ & $106.0 \pm 1.2$ & $-22.9 \pm 0.2$ & $89.2 \pm 1.1$ & $-26.3 \pm 0.1$ & $82.8 \pm 1.0$ \\
\hline Wedge-like & $-22.5 \pm 0.3$ & $107.5 \pm 1.3$ & $-22.2 \pm 0.3$ & $107.4 \pm 3.0$ & $-22.7 \pm 0.2$ & $108.0 \pm 2.3$ \\
\hline Control & $-21.9 \pm 0.3$ & $102.3 \pm 1.4$ & $-22.3 \pm 0.1$ & $99.5 \pm 1.2$ & $-22.0 \pm 0.2$ & $99.2 \pm 1.5$ \\
\hline
\end{tabular}

The specific surface area of the alumina nanopetals is approximately $280 \mathrm{~m}^{2} \cdot \mathrm{g}^{-1}$, and the zeta potential is $30 \pm$ $3 \mathrm{mV}$ (sample 1). The alumina plates (sample 2), which have an irregular shape with a size of 40-100 $\mathrm{nm}$ and a thickness of 4-15 nm, are formed after hydrothermal treatment with AlN/Al nanopowders (Fig. 3b). According to TEM, the products of AlN/Al oxidation in wet air are nonporous wedge-like structures (sample 3) with planar dimensions approximately 150-300 nm (Fig. 3c). The characteristics of the low-dimensional nanostructures are summarized in Table 1.

Experimental results revealed that alumina nanostructures have effect on viability and zeta-potential of tumor cells (Table 2). After 12, 24 and 48 hours of nanopetals exposure on Neuro-2a cells the viability decreased from $100.5 \pm 3.2$ to $64.4 \pm 3.3 \%$. At the same time, zeta-potential of the cells slightly changed to more negative values $(-25.3 \pm 0.2)$ than that of the control ones $(-21.9 \pm 0.3)$ even after 12 hours of contact with nanopetals. This tendency continued after 24 and 48 hours of exposure, with zeta-potential being $-26.3 \pm 0.2$ and $-29.4 \pm 0.3$, respectively. No change in zeta potential was detected after 12 and 24 hours of incubation with nanoplates. There was also some effect on viability of the cells. The maximum decrease in zeta-potential was observed after 48 hours of exposure, and viability of the cells also reduced. Table 2 shows that wedge-like alumina structures did not affect Neuro-2a tumor cells at all the time points.

According to the results obtained using the DLS technique, the average zeta potential of cells after the contact with nanostructures shifted towards negative values, as compared to the control ones. It is presumably a result of redistribution of phosphatidylserine bearing a negatively charged carboxyl group from the inner to the outer lipid layer. The emergence of phosphatidylserine in the outer lipid monolayer of the cell membrane is one of the earliest markers of apoptosis and reduction in cell viability [22].

\section{CONCLUSION}

Aluminum oxide nanostructures were obtained under laboratory conditions with various morphologies and specific surface areas, but having the same zeta-potential $(30 \mathrm{mV})$. The study of zeta-potential change of tumor cells after exposure to nanostructures was performed. It revealed that the biggest change of zeta-potential and viability of the cells was observed with nanopetals. Nanoplates had less effect on zeta-potential and cell proliferation change. Wedge-like alumina did not exhibit any effect on zeta-potential and viability of the cells. Thus, measurement of zeta-potential of the cells or cell surface charge with the DLS technique is a significant criterion that gives information about cell proliferation. It was proved that zeta-potential is an early marker of the altered cell viability.

\section{ACKNOWLEDGMENTS}

The synthesis and characterization of flower-shaped micro/nanostructures and the cytotoxicity evaluation were produced under the financial support of the Russian Science Foundation (Grant No. 14-23-00096).

The study reported in this article was conducted according to accepted ethical guidelines involving research in humans and/or animals and was approved by an appropriate institution or national research organization.

The study is compliant with the ethical standards as currently outlined in the Declaration of Helsinki.

All individual participants discussed in this study, or for whom any identifying information or image has been presented, have freely given their informed written consent for such information and/or image to be included in the published article. 


\section{REFERENCES}

1. K. W. Short, S. Carpenter, J. P. Freyer, and J. R. Mourant, Biophys J. 88, 4274-4288 (2005).

2. H. E. Cole, A. Demont, and I. W. Marison, Processes 3, 384-405 (2015).

3. C. Li and M. Liu, FEBS Lett. 587, 1008-1011 (2013).

4. Y. Zhang, M. Yang, N.G. Portney, D. Cui, G. Budak, E. Ozbay, M. Ozkan, and C. S. Ozkan, Biomed. Microdevices 10, 321-328 (2008).

5. O. V. Bondar, D. V. Saifullina, I. I. Shakhmaeva, I. I. Mavlytova, and T. I. Abdullin, Acta Naturae 1, 78-81 (2012).

6. E. Hondroulis, R. Zhang, C. Zhang, C. Chen, K. Ino, T. Matsue, and C. Z. Li, Theranostics 4, 919-930 (2014).

7. G. J. Owens, R. K. Singh, F. Foroutan, M. Alqaysi, C. M. Han, H. W. Kim, and J. C. Knowles, Progress Mater. Sci. 77, 1-79 (2016).

8. L. G. Boros, M. Cascante, and W. N. Lee, Drug Discovery Today 7, 364-372 (2002).

9. A. Santos, G. Kaur, A. Evdokiou, and D. Losic, Biomaterials 35, 5517-5526 (2014).

10. D. H. Kwak, J. B. Yoo, and D. J. Kim, J. Nanosci. Nanotechnol. 10, 345-348 (2010).

11. H. Ichii, L. Inverardi, and A. Pileggi, Am. J. Transplant. 5 1635-1645 (2005).

12. J. Ferré-Borrull, J. Pallarès, G. Macías, and L. F. Marsal, Materials 7, 5225-5253 (2014).

13. O. V. Bakina, N. V. Svarovskaya, E. A. Glazkova, A. S. Lozhkomoev, E. G. Khorobraya, and M. I. Lerner, Adv. Powder Technol. 26, 1512-1519 (2015).

14. O. V. Bakina, E. A. Glazkova, N. V. Svarovskaya, A. S. Lozhkomoev, E. G. Khorobraya, and S. G. Psakhie, AIP Conf. Proc. 1623, 35 (2014).

15. A. S. Lozhkomoev, E. A. Glazkova, S. O. Kazantsev, I. A. Gorbikov, O. V. Bakina, N. V. Svarovskaya, and S. G. Psakhie. Nanotechnolog. Russ. 10, 858-864 (2015).

16. A. S. Lozhkomoev, E. A. Glazkova, O. V. Bakina, M. I. Lerner, I. Gotman, E. Y. Gutmanas, S. O. Kazantsev, and S. G. Psakhie, Nanotechnology 27, 205603-205609 (2016).

17. N. V. Kirilova, A. N. Fomenko, and M. S. Korovin, AIP Conf. Proc. 1688, 030018 (2015).

18. M. I. Lerner, E. A. Glazkova, A. S. Lozhkomoev, N. V. Svarovskaya, O. V. Bakina, A. V. Pervikov, and S. G. Psakhie, Powder Technology 295, 307-314 (2016).

19. M. I. Lerner, A. V. Pervikov, E. A. Glazkova, N. V. Svarovskaya, A. S. Lozhkomoev, and S. G. Psakhie, Powder Technology 288, 371-378 (2016).

20. N. V. Svarovskaya, A. V. Berenda, O. V. Bakina, E. A. Glazkova, A. S. Lozhkomoev, E. G. Khorobraya, and A. N. Fomenko, Progr. Nat. Sci. Mater. Int. 25, 1-5 (2015).

21. A. S. Lozhkomoev, E. A. Glazkova, N. V. Svarovskaya, O. V. Bakina, S. O. Kazantsev, and M. I. Lerner, AIP Conf. Proceed. 1683, 020128-1 (2015).

22. O. V. Bondar, D. V. Saifullina, I. I. Shakhmaeva, I. I. Mavlyutova, and T. I. Abdullin, Acta Nat. 4(12), 78-81 (2012). 